\title{
Evapotranspiration flux partitioning at a multi-species shrubland with stable isotopes of soil, plant, and atmosphere water pools
}

\author{
Tonantzin TARIN ${ }^{1,2}$, Enrico A. YÉPEZ ${ }^{1,3 *}$, Jaime GARATUZA-PAYÁN ${ }^{1,3}$, Julio C. RODRÍGUEZ $^{4}$, \\ Luis A. MÉNDEZ-BARROSO ${ }^{1}$, Christopher J. WATTS ${ }^{5}$ and Enrique R. VIVONI ${ }^{4,6}$ \\ ${ }^{1}$ Instituto Tecnológico de Sonora, Departamento de Ciencias del Agua y Medio Ambiente, 5 de Febrero 818 sur, Col. \\ Centro, 85000 Ciudad Obregón, Sonora, México. \\ ${ }^{2}$ Department of Plant and Soil Sciences, University of Delaware, Newark, Delaware, USA. \\ ${ }^{3}$ Sede Regional Sur de Sonora, Laboratorio Nacional de Geoquímica y Mineralogía, 5 de febrero 818 sur, Col. Centro, \\ 85000 Ciudad Obregón, Sonora, México. \\ ${ }^{4}$ Universidad de Sonora, Departamento de Agricultura y Ganadería, Blvd. Encinas y Rosales, Col. Centro, 83000 \\ Hermosillo, Sonora, México. \\ ${ }^{5}$ Universidad de Sonora, Departamento de Física, Blvd. Encinas y Rosales, Col. Centro, 83000 Hermosillo, Sonora, \\ México. \\ ${ }^{6}$ Arizona State University, School of Earth and Space Exploration, Tempe, 85287 Arizona, USA. \\ ${ }^{7}$ Arizona State University, School of Sustainable Engineering and the Built Environment, 85287 Tempe, Arizona, USA. \\ *Corresponding author; email: yepezglz@gmail.com
}

Received: April 24, 2019; accepted: February 4, 2020

\section{RESUMEN}

La evapotranspiración es el segundo componente más grande del ciclo hidrológico, después de la precipitación, en regiones semiáridas como el noroeste de México. En este estudio, separamos el flujo de evapotranspiración (ET) usando isótopos estables de agua en el continuo suelo-planta-atmósfera en combinación con mediciones de flujo de covarianza de vórtices. Consideramos tres métodos para determinar la composición isotópica de la transpiración $\left(\delta_{T}\right): 1$ ) estado isotópico estable (ISS), 2) estado isotópico no estable (NSS), y 3 ) estado isotópico no estable ponderando la importancia relativa (RI) de la cobertura de especies dominantes y teniendo en cuenta los valores relativos de conductancia estomática. Se estimaron tres enfoques de separación T/ET durante varios días húmedos y secos en el sitio de estudio en Sonora, México. El flujo de ET total fue variable a lo largo de los años debido a las diferencias en la cantidad de precipitación entre años. ET fue menor durante el año más seco y alcanzó valores más altos durante el año más húmedo. La evaporación del suelo (E) dominó la ET poco después de grandes eventos de lluvia (40 a 70 mm d ${ }^{-1}$ [DOY-196 y DOY-197 en 2008]), pero mostró una rápida disminución a medida que se secaba la superficie del suelo. Los valores estimados de T/ET basados en un balance de masa isotópico estaban en el mismo rango, independientemente de los tres métodos utilizados. La relación T/ET media en todos los periodos estudiados estuvo en el rango de otros estudios en ecosistemas semiáridos y tendencias globales con valores de $\sim 0.67 \pm 0.02$. Este trabajo contribuye a una mejor comprensión de las interacciones de la atmósfera superficial en las regiones semiáridas.

\section{ABSTRACT}

Evapotranspiration is the second largest component of the hydrological cycle after rainfall precipitation in semiarid regions such as northwestern Mexico. In this study, we partitioned the evapotranspiration (ET) flux using stable isotopes of water in the soil-plant-atmosphere continuum in combination with eddy covariance flux measurements. We considered three methods for determining the isotopic composition of transpiration $\left(\delta_{T}\right)$ : (1) isotopic steady state, (2) non-steady state, and (3) non-steady state weighting the relative importance 
of dominant species cover and accounting for the relative values of stomatal conductance. Three approaches of T/ET partitioning were estimated during several wet and dry days at the study site in Sonora, Mexico. The total ET flux was variable across years due to differences in precipitation amount between years. ET was lower during the drier-year and reached higher values during the wetter-year. Soil evaporation (E) dominated ET soon after large rain events (40 to $70 \mathrm{~mm} \mathrm{~d}^{-1}$ [DOY-196 and DOY-197] in 2008) but showed a rapid decrease in dominance as the soil surface dried. Estimated values of T/ET based on an isotopic mass balance were in the same range independent of three methods used. The mean T/ET ratio across all the periods studied was in the range of other studies in semiarid ecosystems and global trends with values of $\sim 0.67 \pm 0.02$. This work contributes to a better understanding of the surface atmosphere interactions in semi-arid regions.

Keywords: ecohydrology, subtropical ecosystem, water availability, Keeling plots, North American monsoon.

\section{Introduction}

Evapotranspiration (ET) is a fundamental ecosystem process that transfers large amounts of water from the surface to the atmosphere via soil evaporation (E) and plant transpiration (T) (Shuttleworth, 2006; Kool et al., 2014). ET is a combined flux largely related to the Earth energy balance, and strongly controlled by the vegetation structure and physiological processes (Jasechko et al., 2013; Wang et al., 2014). Water is transferred to the atmosphere from soil moisture surfaces and plant leaves (but not solely) pools. $\mathrm{T}$ is the loss of water from plants through stomata pores which open during photosynthesis and stomatal opening links the water and $\mathrm{C}$ cycles in terrestrial ecosystems (Nobel, 2009). Stomatal conductance is a measure of the rate of flux of either water vapor or $\mathrm{CO}_{2}$ through stomatal pores (Nobel, 2009). Therefore, there is a link between ecosystem productivity and water fluxes commonly studied as water-use efficiency (Huxman et al., 2005; Seibt et al., 2008; Eamus et al., 2013).

Arid and semi-arid regions represent $45 \%$ of the terrestrial surface and in these regions, ET is over $80 \%$ of the total precipitation (Chapin et al., 2002; Biederman et al., 2016). Despite that the ratio of $\mathrm{T}$ to ET (T/ET) is highly variable. There is a tendency for $\mathrm{T}$ to be the dominant flux, especially in semi-arid ecosystems due to their dependency on water (Reynolds et al., 2000; Yépez et al., 2007; Raz-Yassef et al., 2010; Vivoni, 2012). A worldwide review by Schlesinger and Jasechko (2014) showed that T can represent $61 \%$ of ET in different types of ecosystems, and around $51 \%$ in many shrublands and deserts.

Ecosystems where a larger proportion of ET comes through $\mathrm{T}$ (high T/ET ratio) will be more productive than those with a low T/ET (Huxman et al., 2005;
Ponce-Campos et al., 2013). Nevertheless, there is little information that provides empirical estimates of T/ET at ecosystem scales (Newman et al., 2006; RazYassef et al., 2010; Jasechko et al., 2013; Schlesinger and Jasechko, 2014; Stoy et al., 2019) and its relation to carbon fluxes (Scott et al., 2006; Yépez et al., 2007; Ponce-Campos et al., 2013), which limits our understanding of ecohydrological processes of arid and semi-arid ecosystems (Newman et al., 2006).

Techniques to measure ET have improved significantly to address questions regarding ecosystems functioning and water balance (Shuttleworth, 2006; Kool et al., 2014; Stoy et al., 2019). Modeling approaches are also commonly used to provide information about $\mathrm{T}$ and $\mathrm{E}$ estimates (Reynolds et al., 2000; Méndez-Barroso et al., 2014; Kool et al., 2014). Although modeled estimates of ET components are useful to account for water budgets, field validation data are needed to refine models at the appropriate scales.

A few techniques exist to partition ET in its components; yet the fundamental problem is the spatial representation to separate measurements of $\mathrm{E}$ or $\mathrm{T}$ at a consistent scale with ecosystem studies. For example, leaf chambers or porometer techniques allow estimation of $\mathrm{T}$ on a single leaf (Wang and Yakir, 2000); sap flow methods determine $T$ of individual trees; soil E can be estimated using flow chambers positioned above the soil surface (Raz-Yaseef et al., 2010), or with lysimeters that estimate E by accounting changes in soil water content (Wenninger et al., 2010). However, the error propagation when scaling these methods to an entire ecosystem is substantial (Wilson et al., 2001; Kool et al., 2014). The eddy covariance technique (EC) provides a direct and continuous estimate of ET within an ecosystem 
and does not directly distinguish the contributions of its individual components (Li et al., 2019). Recent studies have been able to partition ET via water-use efficiency as the ratio of gross primary productivity (GPP) and ET (Zhou et al., 2016; Scanlon and Kustas, 2010). However, large uncertainties are associated to the estimation of GPP, which is not measured but modeled (Reichstein et al., 2005), which is an important issue for the partitioning of ET (Tarin et al., 2020). Therefore, the study of ET and its components demand a combination of techniques (Williams et al., 2004; Raz-Yassef et al., 2009; Stoy et al., 2019). Combining EC and stable isotope techniques is an alternative that allows ET partitioning ecosystems-scales (Williams et al., 2004; Yépez et al., 2007; Good et al., 2012; Tarin et al., 2014). This is possible since the stable isotopes of water can be used as tracers of the hydrological cycle due to their different fractionation processes that are predictable using parameters such as temperature and humidity (Yakir and Sternberg, 2000).

In this study, we aimed to estimate the fraction plant $\mathrm{T}$ that corresponds to the total ET flux (T/ET) in a semi-arid ecosystem in the northwest of Mexico. The northwest hydroclimate of Mexico is strongly controlled by the North American Monsoon (NAM) system (Watts et al., 2007; Vivoni et al., 2008), which delivers most of the annual precipitation during the warm summer from June to September (Lizárraga-Celaya et al., 2010). Thus, semi-arid ecosystems in the northwest of Mexico are highly depend on water availability. We used isotopic measurements of water samples from stems, soils and atmospheric vapor in a multi-species ecosystem and continuous measurements of ET from the EC method. We considered the contribution of multiple species for the estimation of the isotopic composition of $\mathrm{T}\left(\delta_{\mathrm{T}}\right)$ at an ecosystem-scale. Therefore, the specific objective was not only to compare and test different approaches for estimating T/ET using the stable isotope technique, but also to incorporate a weighting of the species-specific physiological traits such as stomatal conductance and the relative plant cover in the final estimation of $\delta_{\mathrm{T}}$, which has not been previously assessed for this application.

\subsection{Stable isotope: theory}

The stable isotope ratio of an element is represented by the notation $\delta$, which relates measured values to a standard as: $\delta=\left[\left(R_{\text {sample }} / R_{\text {standard }}\right)-1\right] \times 1000$, where $R_{\text {sample }}$ and $R_{\text {standard }}$ are molar ratios of heavy isotopes over light isotopes $\left({ }^{2} \mathrm{H} /{ }^{1} \mathrm{H}\right.$ and $\left.{ }^{18} \mathrm{O} /{ }^{16} \mathrm{O}\right)$ present in a sample and the standard mean ocean water (SMOW), respectively (Ehleringer et al., 2000). The $\delta$ value is in units of parts per thousand (\%o). The isotopic model to estimate the ratio of $\mathrm{T}$ to ET is fundamentally based on a mass balance approach (Yakir and Sternberg, 2000):

$$
\frac{T}{E T}=\frac{\left(\delta_{E T}-\delta_{E}\right)}{\left(\delta_{T}-\delta_{E}\right)}
$$

where T/ET represents the ratio of $\mathrm{T}$ to total $\mathrm{ET}$ flux; $\delta_{E T}$ is the isotopic composition of ET which is determined by the Keeling plot approach using isotopic measurements of water vapor and vapor concentrations within a gradient (Wang and Yakir, 2000); is the isotopic composition of T, and $\delta_{E}$ is the isotopic composition of the vapor from $\mathrm{E}$ (Craig and Gordon, 1965).

The fundamental concept of the Keeling approach is that there are only two different sources of water to ET and this allows the identification of the isotopic composition of the source ET flux, $\delta_{E T}$ (Wang and Yakir, 2000; Pataki et al., 2003; Wang et al., 2015). Traditionally, the isotopic composition of water vapor has been monitored using a cold trap method (Helliker et al., 2002), while recent studies have used laser spectroscopy systems (Wang et al., 2010; Griffis, 2013; Good et al., 2014; Sun et al., 2014). Even though laser spectroscopy technology with a resolution of one second is commercially available, there are several problems that have not been resolved yet. For example, the real-time method requires a gradient of moisture (Wang et al., 2015), and robust calibrations have to be implemented continuously with a known isotopic composition during the measurements in laboratory or field experiment (Rambo et al., 2011; Good et al., 2012).

The Craig and Gordon (1965) model can be applied to estimate the isotopic composition of $\mathrm{E}\left(\delta_{\mathrm{E}}\right)$ using the isotopic composition of soil water as:

$$
\delta_{E}=\frac{\alpha^{*} \delta_{L}-h \delta_{a}-\varepsilon^{*}-(1-h) \varepsilon_{k}}{(1-h)+(1-h)\left(\frac{\varepsilon_{k}}{1000}\right)}
$$

where $\delta_{L}$ is the isotopic composition of liquid water at the evaporating front in the soil (usually 0.05 to $0.1 \mathrm{~m}$ 
depth); $\delta_{a}$ is the isotopic composition of the background atmospheric water vapor $(0.1 \mathrm{~m}$ above the soil surface); $\alpha^{*}$ is an equilibrium fractionation factor that is temperature dependent $\left[\alpha^{*}=(1.137\right.$ $\left.\left.\left(10^{6} / T_{\text {soil }}{ }^{2}\right)-0.4156\left(10^{3} / T_{\text {soil }}\right)-2.0667\right) / 1000+1\right]$ with $T_{\text {soil }}$ in degrees Kelvin (Majoube, 1971); $\varepsilon^{*}=$ $\left(1-\alpha^{*}\right) \times 10^{-3} ; \varepsilon_{k}$ is the kinetic fractionation factor for oxygen (1.0189 in a static boundary layers; Merlivat, 1978); and $h$ is the relative humidity normalized to the temperature of the soil surface. In general, Eq. (2) calculates how evaporating vapor is depleted in heavy isotopes relative to the evaporating water body (soil water moisture). Depletion of the heavy isotope occurs because the lighter isotope diffuses faster than the heavier isotope.

Contrary to the estimation of $\delta_{E}$ and $\delta_{E T}, \delta_{T}$ can be estimated in different ways. The simplest way is to assume that T occurs at an isotopic steady state (ISS), where the isotopic composition of water in stems (in this case the source of water; $\delta_{s}$ ) is assumed to be the same as the water being transpired by the canopy (Yakir and Sternberg, 2000; Yépez et al., 2003). This condition is in fact possible since plants do not accumulate heavy or light isotopes and should be valid at daily timescales. However, at an instantaneous-scale, plants may not transpire at steady state due to transient changes in atmospheric conditions and the physiological state of the plants, for example regulation of stomatal conductance (Farquhar and Cenusak, 2005). In order to calculate a $\delta_{T}$ value in isotopic non-steady state (NSS) conditions, we can first model the isotopic composition of water at the sites of evaporation following Farquahar and Cenusak (2005) and then apply the Craig and Gordon model (Eq. [2]). Measurements of isotopic composition of leaf water at the sites of evaporation are, however, extremely difficult. Due to the bulk leaf, water often does not represent the actual water that is being transpired and, instead, it is a mixture of unfractionated water from leaf veins that do not evaporate, and heavily fractionated water at the evaporation sites (Farquahar and Cenusak, 2005; Wang et al., 2015). However, an alternative to approximate a reasonable value of leaf water isotopic composition under NSS conditions is given by the Dongmann et al. (1974) model:

$\delta_{e n}(t)=\delta_{e s}(t)-\left[\delta_{e s}(t)-\delta_{e n}(t-1) \exp \left(\frac{-\Delta t}{\tau \varsigma}\right)\right.$ where $\delta_{e n}(T)$ and $\delta_{e n}(T-1)$ are the NSS compositions of the leaf water at time $t$ and at time $(T-1)$, respectively; $\Delta t$ is an interval time in seconds; and $\delta_{e s}(T)$ is the isotopic steady state composition of leaf water at time $t$ based on (Yakir and Stenberg. 2000):

$\delta_{e s}(t)=\delta_{s}+\left(\delta_{s s}-\delta_{s}\right) \cdot\left(1-\exp ^{-p}\right) / p$

where $\delta_{S}$ is the isotopic composition of the stem water and $\delta_{S S}$ is the isotopic composition of bulk leaf water at ISS. The term $p$ is the Péclet number determined as $\left(T_{\text {leaf }} \bullet L\right) /(C \cdot D w)$, where $C\left(55.5 \times 10^{3} \mathrm{~mol} \mathrm{~m}^{-3}\right)$ is the density of water, $D w\left(\mathrm{~m}^{2} \mathrm{~s}^{-1}\right)$ is the diffusivity in water of a given species, $L(\mathrm{~m})$ is the scaled length over which liquid phase diffusion occurs and $T_{\text {leaf }}$ $\left(\mathrm{mol} \mathrm{m} \mathrm{m}^{-2} \mathrm{~s}^{-1}\right)$ is the leaf $\mathrm{T}$ rate (Farquhar and Cernusak, 2005). The isotopic composition of bulk leaf water at ISS is obtained as:

$\delta_{s s}=\delta_{s}+\varepsilon_{e q}+\varepsilon_{k}+h\left(\delta_{a}-\varepsilon_{k}-\delta_{s}\right)$

where $\delta_{a}$ represents the isotopic vapor near the canopy; $\varepsilon_{k}$ is the kinetic fraction in the laminar leaf boundary layer; and $h$ is the relative humidity value at the leaf surface temperature. In Eq. (3), $\Delta t$ is a time interval in seconds and $\tau=W / T_{\text {leaf }}$ represents the turnover time of water in the leaf, where $W$ $\left.(\mathrm{mol} \mathrm{m})^{-2}\right)$ is the molar concentration of leaf water. The term $\varsigma$ relates $\alpha^{*} \alpha_{k}(1-\mathrm{h})$ where $\alpha_{k}$ is the kinetic fraction factor (1.023; Cappa et al., 2003) and $\alpha^{*}$ and $h$ are as in Eq. (3). Thus, the isotopic composition of T at non-steady state (NSS) conditions can be estimated by replacing $\delta_{L}$ with $\delta_{e n}(t)$ in Eq. (2), to obtain $\delta_{T, N S S}$.

Although $\delta_{s s}$ does not estimate the isotopic enrichment at the sites of evaporation, it does represent the instantaneous condition of the leaf water and therefore is useful to represent the isotopic changes at the leaf through time (Flanagan and Ehleringer, 1991; Farquhar and Cernusak, 2005; Lai et al., 2006; Farquhar et al., 2007). Thus, the non-steady state model values of transient leaf water enrichment are a robust approximation of the isotopic composition of leaf water to estimate $\delta_{T}$. Several studies have discussed the importance of accounting an NSS approach to determinate $\delta_{T}$ for ET partitioning studies. For example, Xiao et al. (2012) and Wang et al. (2015) have concluded that complex models (e.g., NSS models considering the Péclet effect) do not 
necessarily add precision to estimates of $\delta_{T}$ in canopy level studies, since the consideration for the NSS assumption affecting estimates of $\delta_{T}$ mainly depends on the time-scale of interest (Cernusak et al., 2016).

\subsection{Proportional contribution of species to}

In this study, we proposed an alternative to estimate $\delta_{T}$ in a multi-species ecosystem. To illustrate this approach, $\delta_{T}$ will be estimated using three different methods: (1) as a simple average of the $\delta_{s}$ of the contributing species hence assuming $\mathrm{T}$ at steady state conditions to give $\delta_{T, I S S}$; (2) as a simple average of $\delta_{T, N S S}$ (accounting for the Péclet effect), which is obtained by replacing $\delta_{L}$ in Eq. (2) with values from $\delta_{e n}(t)$ for each species $\left(\delta_{T, N S S}\right)$; and (3) as in $\delta_{T, N S S}$, but accounting for the relative importance $(R I)$ of each species based on stomatal conductance and plant cover fractions $\left(\delta_{T, R I}\right)$.

The later approach introduced here considers the stomatal conductance fraction of each species relative to the sum of the stomatal conductance values of all species $\left(g_{f}\right)$ and $\left(c_{f}\right)$, which is the canopy vegetation fraction based on the relative aerial canopy cover of each species. The relative contribution of $\delta_{T, N S S}(s p)$ to $\delta_{T}$ was determined as:

$\delta_{T, R I}=\frac{\sum_{i=1}^{n} \delta_{T, N S S(s p)} c_{f_{i}} g_{f_{i}}}{\sum_{i=1}^{n} c_{f_{i}} g_{f_{i}}}$

and involves weighting the isotopic composition of each species $(s p)$ with the product of their contributions to total canopy cover $\left(c_{f}\right)$ and stomatal conductance $\left(g_{f}\right)$ for the $n$ number of species considered. This leads to a weighted average accounting for the relative importance of each species in $\left(\delta_{T, R I}\right)$.

\section{Material and methods}

\subsection{Study location}

The study site is a subtropical shrubland near the town of Rayón, Sonora at coordinates $110.53^{\circ} \mathrm{W}$, $29.74^{\circ} \mathrm{N}$ at $\sim 630 \mathrm{masl}$, and it is part of the MexFlux network (Vargas et al., 2013; Villareal et al., 2016). The climate of the region is semi-arid BSh according to Köppen's classification (Verduzco et al., 2018). Historical mean annual temperature is $21.4{ }^{\circ} \mathrm{C}$ and the precipitation is about $515 \mathrm{~mm}$, with temperatures above $40{ }^{\circ} \mathrm{C}$ in summer and temperatures ranging between 0 and $15{ }^{\circ} \mathrm{C}$ in winter. Dominant species are Fouquieria macdougalii, Acacia cochliacantha, Parkinsonia praecox, Mimosa distachya, Jatropha cordata, and Prosopis velutina. The shrubland is influenced by precipitation of the NAM (Watts et al., 2007), which brings about $60 \%$ of the annual precipitation. For this reason, most of the species at the site lose their leaves in the dry season (from October to June) and recover their greenness in late June or early July. Several hydrological and eco-hydrological studies have been conducted in this site (Vivoni et al., 2010; Méndez-Barroso et al., 2014; Tarin et al., 2014; Verduzco et al., 2018).

Vegetation cover was estimated using seven transects of $100 \mathrm{~m}$ in length around a central point marked by a flux tower. In these transects cover percentage was estimated by summing the aerial canopy of each species crossing the transect relative to the length of the transect. Vegetation height was between 2 to $5 \mathrm{~m}$ with a sparse cover that can reach a maximum leaf area index (LAI) of 1.7 based on the Moderate Resolution Imaging Spectroradiometer (MODIS) product at $500 \mathrm{~m}$. The Normalized Difference Vegetation Index (NDVI) for the site was obtained from MODIS at $250 \mathrm{~m}$, which detects changes in vegetation greenness.

\subsection{Instrumentation}

A $9 \mathrm{~m}$ tower was installed in the subtropical shrubland to make long-term meteorological and eddy covariance measurements of ET as described in detail by Verduzco et al. (2018). In brief, the system consisted of an open path LI7500 infrared gas analyzer that provides simultaneous measurements of both water vapor and carbon dioxide (LI-COR, Lincoln, NE) and a three-dimensional sonic anemometer (CSAT3, Campbell Scientific, Logan, UT) that sampled the atmosphere at a frequency of $10 \mathrm{~Hz}$ using a CR5000 datalogger (Campbell Scientific). Fluxes were calculated at 30 min averaging periods considering typical rotation and density corrections as shown by Scott et al. (2004). Other sensors at $30 \mathrm{~min}$ resolution were installed to measure net radiation (NR-LITE-L, Campbell Scientific), air temperature and relative humidity at 0.1 , 2.5, 4.5 and $9 \mathrm{~m}$ above the ground (HMP45D, Vaisala, Helsinki, Finland) and wind speed and direction (Wind Monitor, Young, MI). Soil moisture $(\theta)$ was measured 
at 0.05 and $0.3 \mathrm{~m}$ depths with two water content reflectometers at the tower (CS616, Campbell Scientific) and precipitation was measured with a tipping bucket rain gauge (TR-525USW, Texas Electronics, Dallas, TX). These data were also averaged over $30 \mathrm{~min}$ intervals, except for precipitation (half-hour sums) and were logged using a CR-23X datalogger (Campbell Scientific). Energy closure was determined using least squares comparison from fluxes: latent heat (LE), sensible heat $(H)$, ground heat $(G)$, and net radiation $\left(R_{n}\right)$. Regressions between turbulent fluxes of $(H+$ LE) against $\left(R_{n}-G\right)$ for all summers had a slope of $0.75( \pm 0.04 ; p$-value $<0.005)$, and intercept of $16( \pm$ 2) $\mathrm{W} \mathrm{m}{ }^{-2}$, a coefficient of determination $\left(\mathrm{R}^{2}\right)$ of 0.93 $( \pm 0.005 ; p$-value $<0.001)$ and an energy balance of $0.83( \pm 0.02 ; p$-value $=0.034)$ (Méndez-Barroso et al., 2014). Potential evapotranspiration $\left(\mathrm{ET}_{\mathrm{P}}\right)$ was estimated following Garatuza-Payán et al. (1998). The relative water content (RWC) was estimated using the measurements of $\theta$ relative to a saturation value of $40 \%$.

\subsection{Soils and stems sample collection}

This study encompasses two years (2007 and 2008) during the NAM season. Field campaigns were performed in different days of the year (DOY) in dry periods (July 22, 23 and 24: DOY-203, DOY-204 and DOY-205 for 2007; July 3 and 4: DOY-185 and DOY186 for 2008), and wet periods (July 27: DOY-208 for 2007; July 14 and 15: DOY-196 and DOY-197 for 2008). Sample collections for isotopic analysis were atmospheric water vapor, soil, and stems. Water vapor was collected using the cold trap method in all study days and clustered in periods. To get a vapor concentration and isotope gradient for Keeling plots, water vapor was caught at corresponding heights of temperature and humidity measurements $(0.1$, $2.5,4.5$ and $9 \mathrm{~m})$. Water vapor was simultaneously collected every two hours from all heights with an automatic cryogenic trapping system (Yépez et al., 2003), which pulled air through low-absorption tubing attached to the tower. Glass traps were submerged in a $-80{ }^{\circ} \mathrm{C}$ alcohol bath over a 30 min collection period (Helliker et al., 2002). Flow rate was regulated to $500 \mathrm{ml} \mathrm{min}^{-1}$ to collect from 30 to $50 \mu \mathrm{L}$ of water in each glass trap.

Stems were collected in four dominant species at the subtropical shrubland: Fouquieria macdougalii,
Acacia cochliacantha, Parkinsonia praecox, and Prosopis velutina $(\mathrm{n}=3$ per species). Stem samples were placed in glass tubes and immediately sealed with Parafilm ${ }^{\circledR}$ to avoid water evaporation. Soil samples were collected from 0.05 to $0.1 \mathrm{~m}$ depths in two different microsites at bare soil and under canopies for a total of six samples per microsite on each collection day.

Water from soils and stems was extracted at the laboratory using the cryogenic distillation method described by West et al. (2006) accepting extractions that confirmed that more than $95 \%$ of the water by weight was obtained. Water samples were analyzed in a cavity ring-down spectroscope (DLT-100, Los Gatos Research, Mountain View, CA). The accuracy of the isotope analysis was $0.4 \%$ in ${ }^{18} \mathrm{O}$ with respect to the LGR standards \#1 and \#5 from Los Gatos (LGR, 2008).

\subsection{Estimates of the isotopic composition of $T, E$ and ET}

Using the measurements of temperature and relative humidity, we estimated the atmospheric moisture concentration at different heights as the water vapor was collected. The inverse of the water content $\left(1 / \mathrm{mg} \mathrm{H}_{2} \mathrm{O} \mathrm{m}^{-3}\right.$ of air) was plotted in $x$-axis, while water vapor isotopic composition was plotted in $y$-axis to produce Keeling plots (Wang and Yakir, 2000). The $y$-intercept of the best linear fit of these plots was used to obtain $\delta_{E T}$.

We averaged the isotopic composition of soil water $\left(\delta_{L}\right)$ to obtain a single value for the $\delta_{E}$ calculation each day (Eq. [2]). The isotopic composition of the stem water $\left(\delta_{s}\right)$ was used to estimate the isotopic composition of T $\left(\delta_{T}\right)$ with three different approaches as follows:

1. $\delta_{T, I S S}$ in ISS, with a simple average of the isotopic composition of the stem water of four different species $\delta_{T, I S S}=1 / n \sum \delta_{S}$.

2. In NSS modeling (Eqs. [3], [4] and [5]), $\delta_{T}$ with Craig and Gordon (1965) was calculated using $\delta_{\text {en }}$ $(t)$ for the four species, to produce $\delta_{T, N S S}(s p)$ and then with the average to obtain $\delta_{T, N S S}$ in the same interval of the Keeling plots;

3. In NSS but adding the relative isotopic contribution $(R I)$ value $\delta_{T, R I_{(s p)}}$ to obtain $\delta_{T, R I}$ (section 1.2).

To estimate $g_{f}$ we measured stomatal conductance in four individuals of all four species during 
periods corresponding to water vapor trapping with a porometer (SC-1 Leaf Porometer Systems, Decagon Devices, Pullman, WA). For each species, $c_{f}$ was adjusted to $100 \%$ based on the percentage cover of the four representative species: F. macdougalii represents $21 \%$, A . cochliacantha $16 \%$, P. praecox $10 \%$, and $P$. velutina $18 \%$. To estimate the turnover time of leaf water ( $\tau$ in Eq. [3]) we used estimates of leaf transpiration $\left(T_{\text {leaf }}\right)$ determined in each species using stomatal conductance values related to vapor pressure deficit. The $W$ value to calculate the turnover time of water in the leaf were 5.3, 9.8, 10.9, and $6.1\left(\mathrm{~mol} \mathrm{~m}^{-2}\right)$ for $A$. cochliacantha, P. praecox, $F$. macdougalii, and $P$. velutina, respectively (Tarin et al., 2014). Thus, $\tau$ was calculated as the difference between $T_{\text {leaf }}$ and $W$ (Eqs. [3] and [4]). In Eq. (5), the kinetic fraction $\left(\varepsilon_{k}\right)$ was given by $\varepsilon_{k}=\left(32 r_{s}+\right.$ $\left.21 r_{b}\right) /\left(r_{a}+r_{b}+r_{s}\right)$, applied for $\delta^{18} \mathrm{O}$ (Wang et al., $2015)$. To estimate the stomatal resistance $\left(r_{s}\right)$ at the daily scale, we used the relation of stomatal conductance and vapor pressure deficit. Aerodynamic and boundary-layer resistance values, $r_{a}$ and $r_{b}$ (in $\mathrm{mol} \mathrm{m} \mathrm{m}^{-2} \mathrm{~s}^{-2}$ ), were 3 and 1 , respectively. The time interval used in Eq. (3) was 1800 seconds, and $0.008 \mathrm{~m}$ was used for $L$ in the Péclet number.

\subsection{Estimation of T/ET and uncertainties}

The mass balance calculation of T/ET was applied using the three different approaches to calculating $\delta_{T}$ in Eq. (1). To calculate the volume of water transpired by vegetation, we used the values results from the T/ ET derived from $\delta_{T, R I}\left(\mathrm{~T} / \mathrm{ET}_{\mathrm{IR}}\right)$. Fraction values of T/ $\mathrm{ET}_{\mathrm{IR}}$ were multiplied by the daily total ET that was continuously measured with the eddy covariance technique in $\mathrm{mm} \mathrm{d}^{-1}$.

The uncertainty in the estimation of T/ET (for the three approaches) was determined using the error propagation tool developed by Phillips and Gregg (2001). This method is based on the standard error of the source proportions and mixing, which considers the errors in the $y$-intercept from Keeling plots for $\delta_{E T}$, standard deviations, standard errors and sample size of the sources $\left(\delta_{E}\right.$ and $\left.\delta_{T}\right)$.

\section{Results}

The monsoon season started between DOY 180 and 190 in both years. Each year had different inputs of precipitation during the NAM (Fig. 1d-h) with 2008 being significantly wetter than 2007 (Table I). Mean daily values of weather showed that 2007 was slightly cooler than 2008 during summer conditions (Table I). However, vapor pressure deficit, wind direction and wind speed were similar for both years.

In 2008, the maximum precipitation event was of $73 \mathrm{~mm} \mathrm{~d}^{-1}$, while in 2007 maximum precipitation was $20 \mathrm{~mm} \mathrm{~d}^{-1}$. Precipitation had a significant effect on ET. During the period between DOY-180 to DOY-215 in 2007, ET represented $30 \%$ of precipitation (total $=119 \mathrm{~mm}$ ), while during the same period in 2008 with $80 \mathrm{~mm}$ more of precipitation, ET represented $50 \%$ of the total precipitation. In 2008, maximum ET value was $5.9 \mathrm{~mm} \mathrm{~d}^{-1}$, in contrast to 2007 that had $2.7 \mathrm{~mm} \mathrm{~d}^{-1}$. Peak values of ET occurred over a short period (Fig. 1c, g), with a small delay after each precipitation pulses.

The RWC in 2008 was over 0.50, whereas in 2007 it showed a maximum value of 0.45 in DOY-209. These differences among years showed the influence of precipitation on ET flux. NDVI was similar in both years, but the maximum NDVI value in 2007 was 0.61 in DOY-209, while in 2008 the maximum NDVI value was 0.67 in DOY-193 due to early precipitation prior to the study period (rainfall during DOY-179 was $14.6 \mathrm{~mm} \mathrm{~d}^{-1}$ ).

\subsection{Isotopic composition of ET and E}

Keeling plots determined the isotopic composition of ET (Table II). $\delta_{E T}$ was more enriched during dry periods in both years compared to wet periods. We observed that for the three days of the dry period in 2007, values of $\delta_{E T}$ were between 0 to $-10 \%$ o $\delta^{18} \mathrm{O}$ (Table II). In contrast, during the wet period in 2007 (DOY-208), after a precipitation pulse of $20 \mathrm{~mm} \mathrm{~d}^{-1}$ (Fig. 1), $\delta_{E T}$ was depleted in heavy isotopes (Table II) showing a value of $-18.91 \% \delta^{18} \mathrm{O}$. In the same way, during dry periods in $2008, \delta_{E T}$ had enriched values in the order of 7 to $-3 \% \delta^{18} \mathrm{O}$, but on DOY-196, when precipitation pulses started, we observed $\delta_{E T}$ as depleted as $-25.53 \%$ o $\delta^{18} \mathrm{O}$.

In both years, we noted that evaporated water from the soil was significantly depleted in heavy isotopes with respect to $\delta_{L}$, showing a difference on the order of $20 \%$ to $30 \%$ o $\delta^{18} \mathrm{O}$ (Fig. 2). In 2008, we observed depletion in $\delta_{L}$ reaching values above to $-10 \%$ in DOY-196. $\delta_{E}$ values tended to be lighter in 

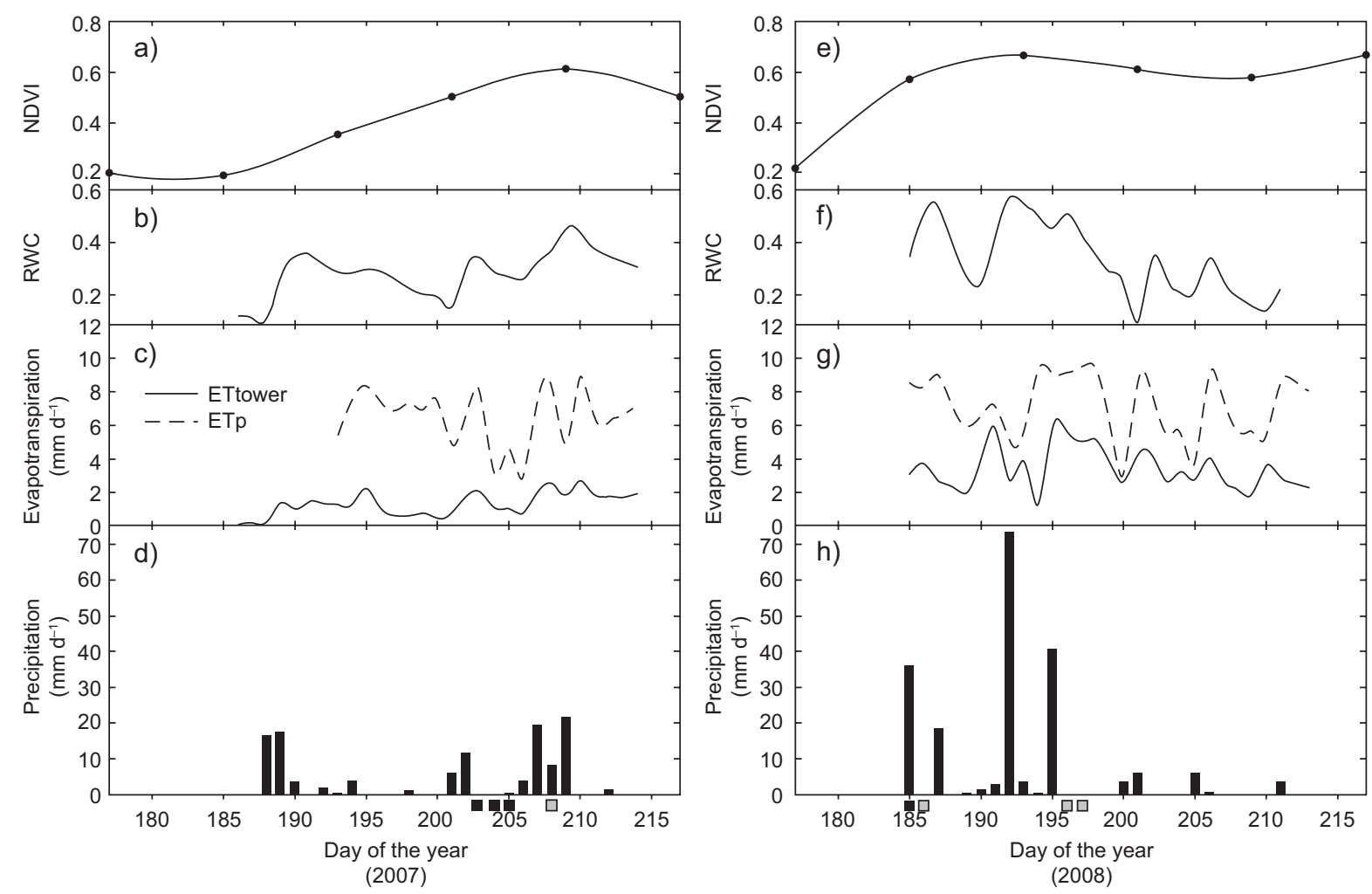

Fig. 1. Environmental conditions of the subtropical shrubland during the North American Monsoon season for 2007 and 2008. (a) and (e) 16-day NDVI composites; (b) and (f) relative soil water content (RWC) at $0.05 \mathrm{~m}$ depth; (c) and $(\mathrm{g})$ ET estimated by the EC technique (ET tower) and potential ET $\left(\mathrm{ET}_{\mathrm{p}}\right)$; (d) and (h) precipitation. Black squares at the bottom of the figure indicate dry days of measurements while grey squares denote wet days of measurements .

Table I. Weather and climate conditions for 2007 and 2008 during the study period (DOY-185 to DOY-220).

\begin{tabular}{|c|c|c|}
\hline \multirow[t]{2}{*}{ Variable } & \multicolumn{2}{|c|}{ Daily average } \\
\hline & 2007 & 2008 \\
\hline Rain (mm) & 143 & 199 \\
\hline $\mathrm{T}_{\text {air }}\left({ }^{\circ} \mathrm{C}\right)$ & $22.4( \pm 2.2)$ & $27.0( \pm 1.8)$ \\
\hline RH (\%) & $51.5( \pm 13.4)$ & $66.1( \pm 9.5)$ \\
\hline VPD (kPa) & $1.8( \pm 1.2)$ & $1.6( \pm 0.5)$ \\
\hline WS $\left(\mathrm{m} \mathrm{s}^{-1}\right)$ & $1.7( \pm 0.3)$ & $1.6( \pm 0.5)$ \\
\hline WD $\left({ }^{\circ \circ}\right)$ & $205.4( \pm 25.7)$ & $191.0( \pm 26.8)$ \\
\hline $\mathrm{T}_{\text {air }}\left(\max ;{ }^{\circ} \mathrm{C}\right)$ & 26.9 & 30.4 \\
\hline $\mathrm{T}_{\text {air }}\left(\mathrm{min} ;{ }^{\circ} \mathrm{C}\right)$ & 18.9 & 23.8 \\
\hline VPD (max; kPa) & 2.54 & 2.19 \\
\hline VPD (min; kPa) & 0.6 & 0.5 \\
\hline
\end{tabular}

$\mathrm{T}_{\text {air }}$ : air temperature; VPD: vapor pressure deficit; WS: wind speed; WD: wind direction.

Maximum daily and minimum values of air temperature and VPD as $\mathrm{T}_{\text {air }}$ max and $\mathrm{T}_{\text {air }} \min , \mathrm{VPD}$ max and VPD min, respectively. this period. There were no differences in $\delta_{E}$ estimates between years: in 2007, $\delta_{E}$ showed values around $-23 \% \pm 2.4 \delta^{18} \mathrm{O}$, while in $2008, \delta_{E}$ showed values in the range of $-28 \% \pm 3.2 \delta^{18} \mathrm{O}$.

\subsection{Isotopic composition of transpiration}

Our methods to estimate the isotopic leaf water enrichment at ISS and NSS did not show significant differences in the first hours (from 6 am to $10 \mathrm{am}$ ) of the day for the four species considered (Fig. 3 only DOY-196 is showed). After $10 \mathrm{am}$, the difference between ISS and NSS increased from $1 \%$ to $\sim 5 \%$ o $\delta^{18} \mathrm{O}$. Prosopis velutina showed the largest difference with $6.15 \%$ in the evening, followed by Fouquieria macdougalii with 4.7\%, Acacia cochliacantha with $4.1 \%$, and Parkinsonia praecox with a difference of $2.14 \%$ o $\delta^{18} \mathrm{O}$. These small differences between NSS and ISS have major implications in the estimation of $\delta_{T}$ (Eqs. [2] and [3]), meaning that $\delta_{T}$ stayed moderately constant through the 
Table II. Regression parameters for Keeling plots of water vapor.

\begin{tabular}{lccrlrrrr}
\hline Year & DOY & $\begin{array}{c}\text { Sampling } \\
\text { times }\end{array}$ & $\mathrm{n}$ & \multicolumn{1}{c}{$\mathrm{R}^{2}$} & Slope & $s$ & $\begin{array}{c}\text { Intercept } \\
\left(\delta_{E T}\right)\end{array}$ & $s$ \\
\hline 2007 & 203 & $7-16 \mathrm{~h}$ & 11 & $0.43^{* *}$ & $-2.5 \mathrm{E}+02$ & $9.5 \mathrm{E}+01$ & $\mathbf{- 0 . 6 0}$ & 6.1 \\
& 204 & $7-11 \mathrm{~h}$ & 7 & 0.15 & $-1.5 \mathrm{E}+02$ & $1.6 \mathrm{E}+02$ & $\mathbf{- 5 . 6 0}$ & 9.7 \\
& 205 & $8-17 \mathrm{~h}$ & 20 & $0.66^{*}$ & $-1.8 \mathrm{E}+02$ & $3.0 \mathrm{E}+01$ & $-\mathbf{7 . 1 3}$ & 1.7 \\
& 208 & $7-17 \mathrm{~h}$ & 16 & $0.40^{*}$ & $6.0 \mathrm{E}+01$ & $2.0 \mathrm{E}+01$ & $\mathbf{- 1 8 . 9 1}$ & 1.1 \\
\hline 2008 & 185 & $17-18 \mathrm{~h}$ & 4 & $0.81^{* * *}$ & $-2.8 \mathrm{E}+04$ & $9.4 \mathrm{E}+04$ & $\mathbf{7 . 5 3}$ & 7.1 \\
& 186 & $7-12 \mathrm{~h}$ & 8 & $0.61^{* *}$ & $-1.7 \mathrm{E}+04$ & $5.4 \mathrm{E}+04$ & $\mathbf{- 3 . 8 9}$ & 3.3 \\
& 196 & $7-11 \mathrm{~h}$ & 7 & 0.38 & $6.0 \mathrm{E}+04$ & $3.5 \mathrm{E}+04$ & $\mathbf{- 2 5 . 5 3}$ & 2.0 \\
& 197 & $8-11 \mathrm{~h}$ & 8 & $0.61^{* *}$ & $-8.2 \mathrm{E}+04$ & $2.6 \mathrm{E}+04$ & $\mathbf{- 1 6 . 3 2}$ & 1.6 \\
\hline
\end{tabular}

$s$ : standard error; $*, * *$ and $* * *$ mean statistical significance with $99 \%, 95 \%$ and $90 \%$, respectively.

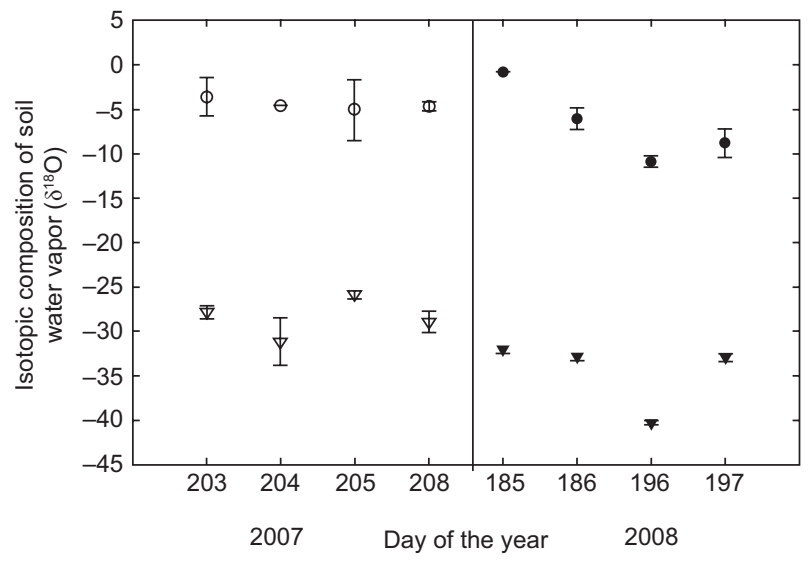

Fig. 2. Isotopic composition of soil water at $0.1 \mathrm{~m}$ depth ( $\delta_{L}$; circles) and the soil evaporation vapor flux ( $\delta_{E}$; triangles) calculated with Eq. (2) for 2007 (open symbols) and 2008 (dark symbols). Values are means \pm standard errors.

day. Ultimately, whether $\delta_{T}$ changes during the day or not, it may affect the T/ET partitioning, as it is explained next.

Values for the different approaches to estimate $\delta_{T}\left(\delta_{T, I S S}, \delta_{T, N S S}\right.$ and $\left.\delta_{T, I R}\right)$ showed enriched values in both years (Fig. 4). Particularly in 2008, these were considerable higher in heavy isotopes with values from 2.56 to $8.54 \%$ o $\delta^{18} \mathrm{O}$, while 2007 showed values from-3.9 to $8.23 \%$ o $\delta^{18} \mathrm{O}$. Differences between the methods $\delta_{T, I S S}$ and $\delta_{T, N S S}$ were more significant in DOY-203 (2007) and DOY-186 (2008); however, these days also showed the larges uncertainties ranging between \pm 2.92 and $\pm 12.91 \%$. In contrast, differences in $\delta_{T, I S S}$ and $\delta_{T, I R}$ were $\sim 4.1 \%$ o $\delta^{18} \mathrm{O}$, and standard errors of both estimates overlapped in the eight days of this study (Fig. 4).

\subsection{Evapotranspiration partitioning}

With the estimation of T/ET using the three approaches to calculate $\delta_{T}$ in Eq. (1), we found that a maximum uncertainty of $30 \%$ in the final estimate of T/ET if using $\delta_{T, I R}$ (Table III). However, the statistical error of the three methods of T/ET fall within the variation expressed by the error propagation (Phillips and Gregg, 2001) and generally overlapped with the simplest approach $\mathrm{T} / \mathrm{ET}_{(\text {ISS) }}$ (Table III).

In 2007, we observed that on DOY-203 and DOY204 , the $\mathrm{T} / \mathrm{ET}_{(\mathrm{RI})}$ ranged between 0.78 and 0.93 in the dry period with a maximum uncertainty of \pm 0.29 , suggesting that $\mathrm{T}$ dominated the total flux of ET in those days. In contrast, during the wet period (DOY208), T/ET decreased to 0.35 with an uncertainty of \pm 0.05 . In 2008, we observed the same pattern as in 2007, T/ET values during dry periods ranged from 1 to 0.74 and from 0.34 to 0.44 in wet days (with uncertainty of 0.19 and 0.05 , respectively). The decrease in error estimations was associated with a decreased vegetation contribution (Fig. 1).

The combination of stable isotopes to calculate $\mathrm{T} / \mathrm{ET}$ and continuous measurements of ET with the eddy covariance technique allowed us to estimate the volume of water transpired by vegetation (Fig. 5). During DOY-203 in 2007, T/ET $\mathrm{RI}_{\text {I }}$ was of $0.93 \pm 0.21$ and the total ET was $2.0 \mathrm{~mm} \mathrm{~d}^{-1}$, meaning that $\mathrm{T}$ was $\sim 1.91 \pm 0.43 \mathrm{~mm} \mathrm{~d}^{-1}$. On DOY-202, there was a precipitation pulse of $11 \mathrm{~mm}$ (Fig. 1), such that T in DOY203 represented $20 \%$ of the water from the previous 


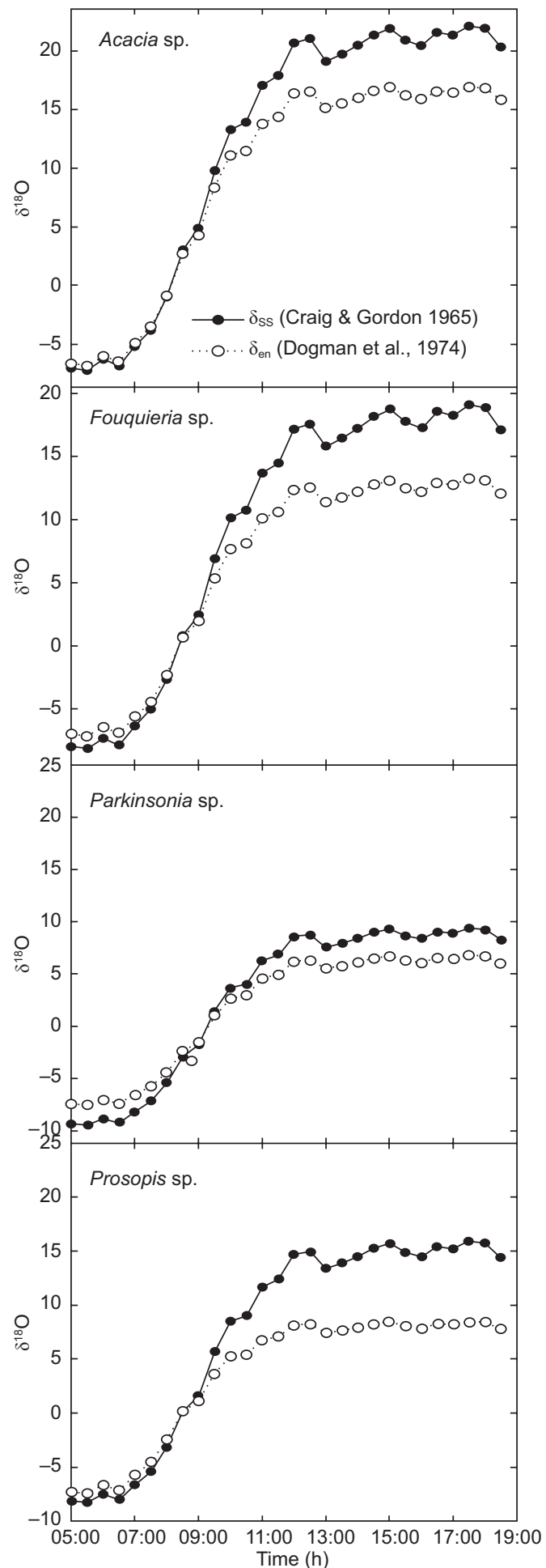

Fig.3. $\delta^{18} \mathrm{O}$-enrichment of leaf water (\%o) of representative species of a subtropical shrubland on DOY-196 of 2008. $\delta_{s S}$ is the predicted enrichment at isotopic steady state, $\delta_{e n}$ is the leaf enrichment under isotopic non-steady state conditions.

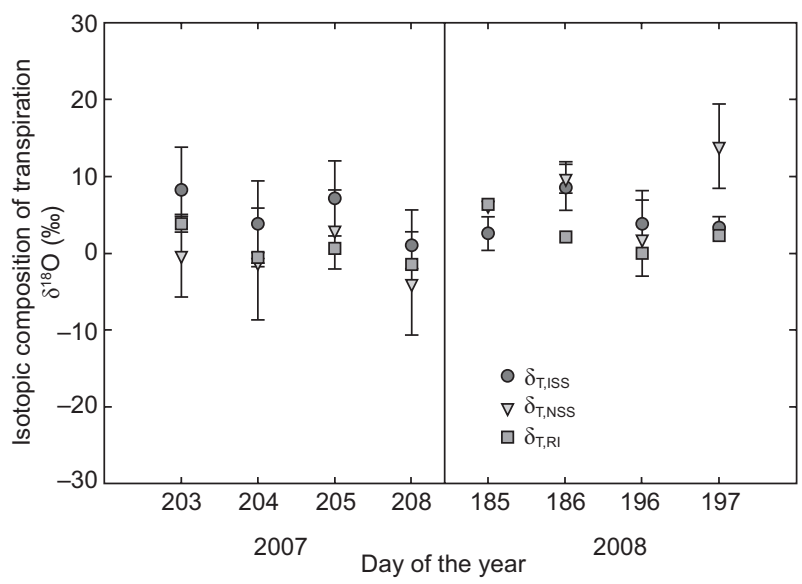

Fig. 4. Isotopic composition of transpiration for key species of the subtropical shrubland, using three different methods: (1) $\delta_{T, I S S}$ is the average isotopic composition of stem water, (2) $\delta_{T, N S S}$ is the modeled isotopic composition of transpiration with the isotopic non-steady state approach, and Péclet effect; and (3) $\delta_{T, R I}$ is considering non-steady state conditions and weighting factors of stomatal conductance and vegetation cover fractions. Symbols are means \pm standard errors.

Table III. T/ET partitioning using three different approaches: T/ET $\mathrm{ETS}_{\text {ISS }}$ using $\delta_{T}$ from $\delta_{I S S}, \mathrm{~T} / \mathrm{ET}_{\mathrm{NSS}}$ using $\delta_{N S S}$ modeled with Craig and Gordon (1965) and T/ET $\mathrm{RI}$ considering $R I$ in isotopic composition of $\mathrm{T}\left(\delta_{R I}\right)$.

\begin{tabular}{ccccc}
\hline Year & DOY & $\mathrm{T}^{2} \mathrm{ET}_{\text {ISS }}$ & $\mathrm{T} \mathrm{ET}_{\mathrm{NSS}}$ & $\mathrm{T} / \mathrm{ET}_{\mathrm{RI}}$ \\
\hline 2007 & 203 & $0.76(0.18)$ & $0.99(0.25)$ & $0.93(0.21)$ \\
& 204 & $0.73(0.29)$ & $0.86(0.25)$ & $0.78(0.29)$ \\
& 205 & $0.57(0.07)$ & $0.65(0.09)$ & $0.62(0.06)$ \\
& 208 & $0.33(0.05)$ & $0.40(0.08)$ & $0.35(0.05)$ \\
\hline 2008 & 185 & $1.00(0.24)$ & $1.00(0.18)$ & $1.00(0.19)$ \\
& 186 & $0.70(0.08)$ & $0.78(0.13)$ & $0.74(0.09)$ \\
& 196 & $0.33(0.05)$ & $0.35(0.06)$ & $0.35(0.05)$ \\
& 197 & $0.46(0.05)$ & $0.35(0.07)$ & $0.44(0.08)$ \\
\hline
\end{tabular}

Values in brackets are uncertainties in accordance with Phillips and Gregg (2001).

precipitation event. For the next two days during this dry period (DOY-204 and DOY-205), ET decreased drastically. ET increased after DOY-207 due to another precipitation event of $20 \mathrm{~mm} \mathrm{~d}^{-1}$, thus T reached its lowest value of $0.65 \pm 0.06 \mathrm{~mm} \mathrm{~d}^{-1}$ during this period. 


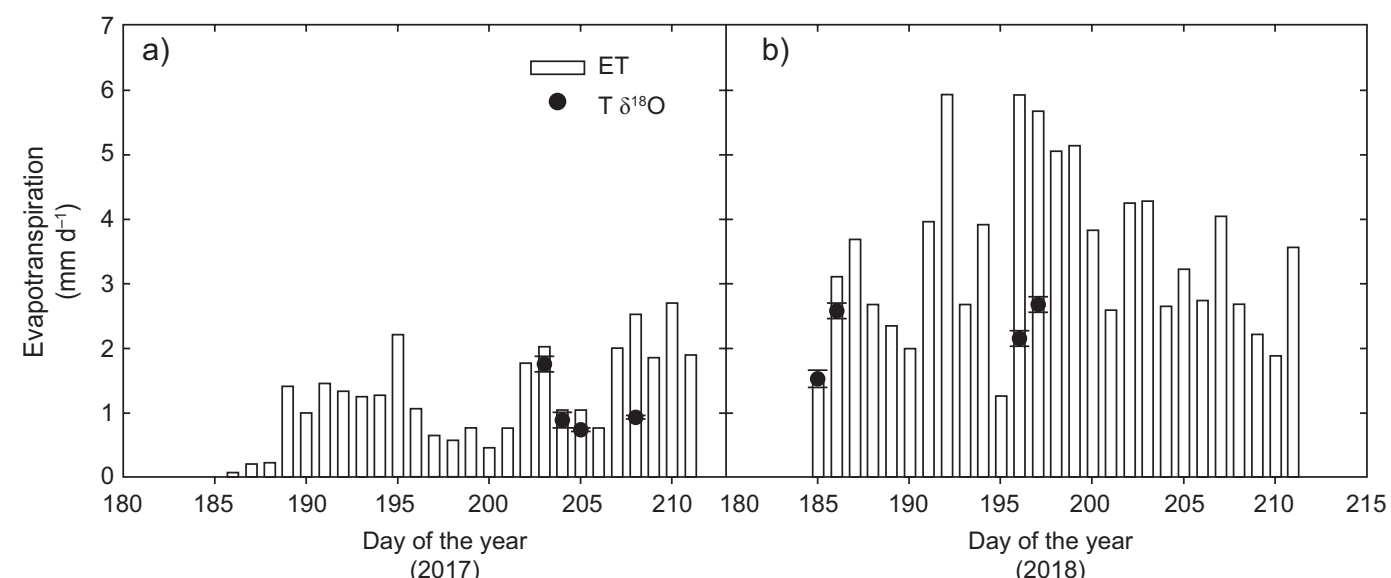

Fig. 5. Daily evapotranspiration (ET) with its transpiration fraction indicated by dark circles. (a) ET in 2007 and (b) ET in 2008. Black circles represent transpiration estimates using the T/ET $\mathrm{R}_{(\mathrm{RI})}$ approach.

Similarly, in 2008 , T was 80 to $100 \%$ of the total ET representing a range of 1.52 to $5.98 \mathrm{~mm} \mathrm{~d}^{-1}$ during the dry period (DOY-185 and DOY-186; note that DOY185 was measured previous a big precipitation pulse which occurred at night [Fig. 1]). The wet period had precipitation pulses of $70 \mathrm{~mm} \mathrm{~d}^{-1}$ in DOY-192 and 40 $\mathrm{mm} \mathrm{d}^{-1}$ in DOY-195 and thus, E was the dominant flux over this period (Fig. 5b). On DOY-196 and DOY-197, soil E was 3.86 and $3.17 \mathrm{~mm} \mathrm{~d}^{-1}$, respectively, while the vegetation greening was at its maximum (Fig. 1).

\section{Discussion}

The present study provides insights on the variability of the T/ET ratio in a semi-arid shrubland under the influence of the NAM in northwest Mexico. Here we combined stable isotopes of water and the eddy covariance technique using three different approaches for the estimation of the isotopic composition of $\mathrm{T}$ $\left(\delta_{T}\right)$. We found that $\mathrm{E}$ was the dominant flux right after large precipitation pulses $\left(>40 \mathrm{~mm} \mathrm{~d}^{-1}\right)$, but $\mathrm{T}$ dominated with up to $100 \%$ over ET as the relative water content declined. Uncertainties in the final estimate of T/ET increased as the complexity of $\delta_{T}$ increased by weighing the proportion of stomatal conductance and vegetation cover for dominant species at the semi-arid shrubland. Our results for this new estimate on $\delta_{T}$ in a multi-species ecosystem and implications on eco-hydrological processes are discussed in the following sections.

\subsection{Different estimates of T/ET and uncertainties}

The novelty of our work relied in the incorporation of physiological and ecological attributes in the stable isotopic approach in a multi-species semi-arid ecosystem. Studies have shown that factors such as vegetation cover, and plant physiological processes, such as stomatal conductance, are important drivers of ecosystem transpiration (Reynolds et al., 2000; Farquhar et al., 2007). Therefore, this study considered the relative importance (RI) of two factors in calculating $\delta_{T}$ (stomatal conductance and vegetation cover) in an isotopic non-steady state condition. Results of T/ET using $\delta_{T, R I}$ showed that considering non-isotopic steady state conditions and weighting the relative importance of species cover and instantaneous stomatal conductance relative values does not considerably improve the expression of $\delta_{T}$ for the mass balance calculation of T/ET (Eq. [1]). These findings are in agreement with previous studies that have shown that a simple steady state is appropriate to calculate T/ET at large spatial-scales, for example at an ecosystem-scale (Xiao et al., 2012; Wang et al., 2015).

A large range of uncertainties was observed (from 5 to $29 \%$ ) in the final estimation of T/ET with the three methods used (Table III). T/ET IR had the largest errors, but similar to those observed with the simplest approach that averaged the isotopic compositions of water from stems assuming steady state conditions (29\%; Table III). Thus, T/ET results tended to 
overlap regardless of the $\delta_{T}$ value used, and this can be explained by the lack of differences between the different calculations of $\delta_{T}$ (Fig. 4). Uncertainties in the estimation of T/ET for the subtropical shrubland with multi-species are similar to ecosystems with one or two dominant species, where the magnitude of errors range between 15 to 30\% (Yépez et al., 2005, 2007; Xu et al., 2008; Bijoor et al., 2011, Good et al., 2012). However, an uncertainty of almost $30 \%$ in $\mathrm{T} /$ ET estimation is higher than the $20 \%$ observed in a semiarid grassland (Yépez et al., 2005) and riparian woodlands (Yépez et al., 2007). Our findings provide important information for the design of future experiments in multi-species ecosystems since steady state assumptions of transpiration may be reasonable for the estimates of T/ET, which simplifies fieldwork and error propagation significantly.

Large uncertainties in our estimates of $\mathrm{T} / \mathrm{ET}_{\mathrm{IR}}$ may be due to uncertainties and differences within species in stomatal conductance rates. Further studies to compare plant physiological traits of co-existing species can help to better assess plant species contribution over ecosystem transpiration. Additionally, an adequate representation for ecosystems and global studies calls for techniques that, while maintaining ecosystem-level consistency, incorporate for example a better temporal resolution for key contributing parameters to partitioning ET with isotopic methods (Stoy et al., 2019). Real-time monitoring of the isotopic compositions of water vapor with laser spectroscopy are now possible (Wang et al., 2010, 2015; Good et al., 2012; Wei et al., 2019) and can provide dynamic estimates of T/ET that could validate remote sensing and modeling approaches providing information at even larger spatial scales (Nagler et al., 2007; Vivoni, 2012). We thus concluded that scaling up the model complexity in partitioning ET using the stable isotopes approach should merely depend on the addressed question and particular site characteristics. Knowing the T/ET ratio provides important insights about carbon-water relations in terrestrial ecosystem with both hydrological and ecological implications at an ecosystem-scale.

\subsection{Ecological implications of T/ET estimates}

ET partitioning as the ratio of T/ET across all studied periods ranged from 0.33 to 1.0 (Table III) and this variability can be explained by water availability at the subtropical shrubland. Semi-arid ecosystems such as the subtropical shrubland in northwestern Mexico highly depend on water availability (Verduzco et al., 2018). Trends in T/ET in semi-arid ecosystems have indicated that soil water availability is preferentially used by the vegetation despite that $\mathrm{E}$ is expected to be high because of large open areas (Raz-Yaseef et al., 2010) and high ET potential (Heilman et al., 2009; Brooks et al., 2011). Our results are in the same range of empirical estimates of T/ET in other semiarid ecosystems (Ferreti et al., 2003; Huxman et al., 2005; Scott et al., 2006; Nagler et al., 2007; Raz-Yaseef et al., 2010; Wang et al., 2010) and estimates based on ecological and hydrological modelling approaches (Reynolds et al., 2000; Vivoni, 2012; Méndez-Barrozo et al., 2014; Schlesinger and Jasechko, 2014).

Although small precipitation events $(<5 \mathrm{~mm}$ $\mathrm{d}^{-1}$ ) are dominant in semi-arid ecosystems (Loik et al., 2004), climate change predictions suggest that larger events and more pronounced inter-storm periods may become more characteristic (Zhang et al., 2007), particularly for the NAM region (IPCC, 2013). At the subtropical shrubland, total ET was variable among years because of the different inputs in precipitation. ET was lower during the drier year 2007 than in the wetter year 2008. These differences showed contrasting patterns on ET components. E was only briefly dominant when large precipitation pulses in the subtropical shrubland occurred since soil $\mathrm{E}$ ratios were $\sim 0.70$ of total ET soon after precipitation events (Fig. 5; see DOY-192 and DOY-195 in 2008). However, E rapidly decreased as the soil profile dried down; thus, vegetation transpiration was the dominant component of ET during dry periods and after small precipitation events (i.e., $11 \mathrm{~mm}$ DOY-202). These observations are consistent with other studies in ecosystems with sparse semi-arid vegetation cover (Williams et al., 2004; Yépez et al., 2005, 2007; Scott et al., 2006; Xu et al., 2008; Méndez-Barroso et al., 2014). Our comparison between a dry year and wet year and between precipitation size events provides important evidence of how $\mathrm{E}$ and $\mathrm{T}$ responded to different precipitation amounts.

The T/ET values observed during the monsoon season also had implications on describing ecosystem functioning as controlled by variable precipitation (Huxman et al., 2005). Evaluations of T/ET ratios in 
terrestrial ecosystems and especially in semi-arid ecosystems are crucial not only for hydrological studies but also for a better understanding of the influence of precipitation over ecological functioning within a changing environment.

\section{Acknowledgments}

The present work was possible thanks to the financial support of the Consejo Nacional de Ciencia y Tecnología (CONACYT) with the project (CB2013221014) and the graduate scholarship 232184 for Tarin T. Additional support came from the SEP-PRODEP to ITSON-CA-3, PROFAPI-ITSON, and the National Science Foundation, International Research Experience for Undergraduates program (Grant OISE 0553852). ERV would like to thank the US Fulbright-García Robles and Mexican CONACYT fellowships for support.

\section{References}

Biederman JA, Scott RL, Goulden ML, Vargas R, Litvak ME, Kolb TE, Yepez EA, Oechel WC, Blanken PD, Bell TW, Garatuza-Payán J. 2016. Terrestrial carbon balance in a drier world: The effects of water availability in southwestern North America. Global Change Biology 22:1867-1879. https://doi.org/10.1111/ gcb. 13222

Bijoor NS, Pataki DE, Rocha AV, Goulden ML. 2011. The application of $\delta^{18} \mathrm{O}$ and $\delta \mathrm{D}$ for understanding water pools and fluxes in a Typha Marsh. Plant, Cell and Environment 34, 1761-1775. https://doi.org/10.1111/ j.1365-3040.2011.02372.x

Brooks PD, Troch PA, Durcik M, Gallo E, Schlegel M. 2011. Quantifying regional scale ecosystem response to changes in precipitation: Not all rain is created equal. Water Resources Research 47, 1-13. https://doi. org/10.1029/2010WR009762

Cappa CD, Hendricks MB, DePaolo DJ, Cohen RC. 2003. Isotopic fractionation of water during evaporation. Journal of Geophysical Research 108(D16), 4525. https://doi.org/10.1029/2003JD003597

Cernusak LA, Barbour MM, Arndt SK, Cheesman AW, English NB, Feild TS, Helliker BR, Hollowey-Phillips MM, Holtum JAM, Kahmen A, McInerney FA, Munksgaard NC, Simonin KA, Song X., Stuart-Williams H, West JB, Farquhar GD. 2016. Stable isotopes in leaf water of terrestrial plants. Plant, Cell and Environment 39, 1087-1102. https://doi.org/10.1111/ pce. 12703

Chapin FS, Matson PA, Vitousek PM, eds. 2002. Principles of terrestrial ecosystem ecology. Springer-Verlag New York, USA, 529 pp.

Craig H, Gordon LI. 1965. Deuterium and oxygen-18 variations in the ocean and marine atmosphere. In: Stable isotopes in oceanographic studies and paleotemperatures (Tonyiorgi E, Ed.). Laboratory of Geology and Nuclear Science, Pisa, Italy, 9-130.

Dongmann G, Nürnberg HW, Förstel H, Wagener K. 1974. On the enrichment of $\mathrm{H}_{2}{ }^{18} \mathrm{O}$ in the leaves of transpiring plants. Radiation and Environmental Biophysics 11, 41-52. https://doi.org/10.1007/BF01323099

Eamus D, Cleverly J, Boulain N, Grant N, Faux R, Villalobos-Vega R. 2013. Carbon and water fluxes in an arid-zone Acacia savanna woodland: An analysis of seasonal patterns and responses to rainfall events. Agricultural and Forest Meteorology 182-183, 225 238. https://doi.org/10.1016/j.agrformet.2013.04.020

Ehleringer JR, Roden J, Dawson TE. 2000. Assessing ecosystem-level water relations through stable isotope ratio analyses. In: Methods in ecosystem science (Sala OE, Ed.). Springer, New York, 181-198.

Farquhar GD, Cernusak LA. 2005. On the isotopic composition of leaf water in the non-steady state. Functional Plant Biology 32, 293-303. https://doi.org/10.1071/ FP04232

Farquhar GD, Cernusak LA, Barnes B. 2007. Heavy water fractionation during transpiration. Plant Physiology 143, 11-8. https://doi.org/10.1104/pp.106.093278

Ferretti DF, Pendall E, Morgan JA, Nelson JA, LeCain D, Mosier AR. 2003. Partitioning evapotranspiration fluxes from a Colorado grassland using stable isotopes: Seasonal variations and ecosystem implications of elevated atmospheric $\mathrm{CO}_{2}$. Plant and Soil 254, 291-303. https://doi.org/10.1023/A:1025511618571

Flanagan LB, Ehleringer JR. 1991. Stable isotope composition of stem and leaf water. Applications to the study plant water use. Functional Ecology 5, 270-277. https:// doi.org/10.2307/2389264

Garatuza-Payán J, Shuttleworth WJ, Encinas D, McNeil DD, Stewart JB, de Bruin H, Watts C. 1998. Measurement and modeling evaporation for irrigated crops in northwest México. Hydrological Processes 12, 1397-1418. https://doi.org/10.1002/(SICI)1099_ 1085(199807)12:9<1397::AID-HYP644>3.0.CO;2-E 
Good SP, Soderberg K, Guan EG, King TM, Scanlon, Caylor KK. 2014. $\mathrm{d}^{2} \mathrm{H}$ isotopic flux partitioning of evapotranspiration over a grass field following a water pulse and subsequent dry down. Water Recourses Research 50, 1410-1432. https://doi. org/10.1002/2013WR014333

Good SP, Soderberg K, Wang L, Caylor KK. 2012. Uncertainties in the assessment of the isotopic composition of surface fluxes: A direct comparison of techniques using laser-based water vapor isotope analyzers. Journal of Geophysical Research 117, D15301. https://doi. org/10.1029/2011JD017168

Griffis T. 2013. Tracing the flow of carbon dioxide and water vapor between the biosphere and atmosphere: A review of optical isotope techniques and their application. Agricultural and Forest Meteorology 174-175, 85109. https://doi.org/10.1016/j.agrformet.2013.02.009

Heilman JL, McInnes KJ, Kjelgaard JF, Owens MK, Schwinning S. 2009. Energy balance and water use in a subtropical karst woodland on the Edwards Plateau, Texas. Journal of Hydrology 373, 426-435. https://doi. org/10.1016/j.jhydrol.2009.05.007

Helliker BR, Roden JS, Cook C. Ehleringer JR. 2002. A rapid and precise method for sampling and determining the oxygen isotope ratio of atmospheric water vapor. Rapid Communication in Mass Spectrometry 16, 929932. https://doi.org/10.1002/rcm.659

Huxman TE, Wilcox BP, Breshears DD, Scott RL, Snyder KA, Small EE, Hultine K, Pockman WT, Jackson RB. 2005. Ecohydrological implications of woody plant encroachment. Ecology 86, 308-319. https://doi. org/10.1890/03-0583

IPCC 2013. Climate Change 2013: The physical science basis. Contribution of Working Group I to the Fifth Assessment Report of the Intergovernmental Panel on Climate Change (Stocker TF, Qin D, Plattner G.-K, Tignor M, Allen SK, Boschung J, Nauels A, Xia Y, Bex V, Midgley PM, Eds.). Cambridge University Press, Cambridge, United Kingdom and New York, NY, USA, 1535 pp.

Jasechko SJ, Sharp ZD, Gibson JJ, Birks SJ, Yi Y, Fawcett PJ. 2013. Terrestrial water fluxes dominated by transpiration. Nature 496, 347-350. https://doi.org/10.1038/ nature 11983

Kool D, Agam N, Lazarovitch N, Heitman JL, Sauer TJ, Ben-Gal A. 2014. A review of approaches for evapotranspiration partitioning. Agricultural and Forest Meteorology 184, 56-71. https://doi.org/10.1016/j. agrformet.2013.09.003
Lai C-T, Ehleringer JR, Bond BJ, Paw UKT. 2006. Contributions of evaporation, isotopic non-steady state transpiration and atmospheric mixing on the $\delta^{18} \mathrm{O}$ of water vapour in Pacific Northwest coniferous forests. Plant, Cell and Environment 29, 77-94. https://doi. org/10.1111/j.1365-3040.2005.01402.x

Li X., Gentine P., Lin C., Zhou S., Sun Z., Zheng Y., Liu J., Zheng C. 2019. A simple and objective method to partition evapotranspiration into transpiration and evaporation at eddy covariance sites. Agricultural and Forest Meteorology 265, 171-182. https://doi. org/10.1016/j.agrformet.2018.11.017

Lizárraga-Celaya C, Watts CJ, Rodríguez JC, Garatuza-Payán J, Scott RL, Saiz-Hernández J. 2010. Spatio-temporal variations in surface characteristics over the North American Monsoon region. Journal of Arid Environments 74, 540-548. https://doi.org/10.1016/j. jaridenv.2009.09.027

Loik ME, Breshears DD, Lauenroth WK, Belnap J. 2004. A multi-scale perspective of water pulses in dryland ecosystems: Climatology and ecohydrology of the western USA. Oecologia 141, 269-281. https://doi. org/10.1007/s00442-004-1570-y

LGR. 2008. Liquid-water isotope analyzer. Automated injection. Los Gatos Research, California, USA.

Majoube M. 1971. Fractionnement en oxygene-18 et en deuterium entre l'eau et sa vapaeur. J. Chimie de Physique 68, 1423-1436. https://doi.org/10.1051/ jcp/1971681423

Méndez-Barroso LA, Vivoni ER, Robles-Morua A, Mascaro G, Yépez EA, Rodríguez JC, Watts CJ, Garatuza-Payán J, Saiz-Hernández J. 2014. A modeling approach reveals differences in evapotranspiration and its partitioning in two semiarid ecosystems in northwest Mexico. Water Resources Research 50, 3229-3252. https://doi.org/10.1002/2013WR014838

Merlivat L. 1978. Molecular diffusivities of $\mathrm{H}_{2}{ }^{16} \mathrm{O}$, $\mathrm{HD}^{16} \mathrm{O}$, and $\mathrm{H}_{2}{ }^{18} \mathrm{O}$ in gases. Journal of Chemical Physics 69, 2864-2871. https://doi.org/10.1063/1.436884

Nagler PL, Glenn EP, Kim H, Emmerich W, Scott RL, Huxman TE, Huete AR. 2007. Relationship between evapotranspiration and precipitation pulses in a semiarid rangeland estimated by moisture flux towers and MODIS vegetation indices. Journal of Arid Environments 70, 443-462. https://doi.org/10.1016/j. jaridenv.2006.12.026

Newman BD, Wilcox BP, Archer SR, Breshears DD, Dahm CN, Duffy CJ, McDowell NG, Phillips FM, Scanlon BR, 
Vivoni ER. 2006. Ecohydrology of water-limited environments: A scientific vision. Water Resources Research 42, 1-15. https://doi.org/10.1029/2005WR004141

Nobel PS. 2009. Physicochemical and environmental plant physiology. 4th ed. Academic Press-Elsevier, San Diego, CA, 582 pp.

Pataki DE, Ehleringer JR, Flanagan LB, Yakir D, Bowling DR, Still CJ, Buchmann N, Kaplan JO, Berry JA. 2003. The application and interpretation of Keeling plots in terrestrial carbon cycle research. Global Biogeochemical Cycles 17, 1022. https://doi. org/10,1029/2001GB001850.

Phillips DL, Gregg JW. 2001. Uncertainty in source partitioning using stable isotopes. Oecologia 127, 171-179. https://doi.org/10.1007/s004420000578

Ponce-Campos GE, Moran MS, Huete A, Zhang Y, Bresloff C, Huxman TE, Eamus D, Bosch DD, Buda RA, Gunter SA, Scalley TH, Kitchen SG, McClaran MP, McNab WH, Montoya DS, Morgan JA, Peters DPC, Sadler EJ, Seyfried MS, Starks PJ. 2013. Ecosystem resilience despite large-scale altered hydroclimatic conditions. Nature 494, 349-352. https://doi.org/10.1038/ nature 11836

Rambo J, Lai C-T, Farlin J, Schroeder M, Bible K. 2011. On-site calibration for high precision measurements of water vapor isotope ratios using off-axis cavity-enhanced absorption spectroscopy. Journal of Atmospheric and Oceanic Technology 28, 1448-1457. https://doi. org/10.1175/JTECH-D-11-00053.1

Raz-Yaseef N, Rotenberg E, Yakir D. 2010. Effect of spatial variations in soil evaporation caused by tree shading on water flux partitioning in a semi-arid pine forest. Agricultural and Forest Meteorology 150, 454462. https://doi.org/10.1016/j.agrformet.2010.01.010

Reichstein M, Falge E, Baldocchi D, Papale D, Aubinet M, Berbigier P, Bernhofer C, Buchmann N, Gilmanov T, Granier A, Grünwald T, Havrankova K, Ilvesniemi H, Janous D, Knohl A, Laurila T, Lohila A, Loustau D, Matteucci G, Valentini R. (2004). On the separation of net ecosystem exchange into assimilation and ecosystem respiration: Review and improved algorithm. Global Change Biology 11, 1424-1439. https://doi. org/10.1111/j.1365-2486.2005.001002.x

Reynolds JF, Kemp PR, Tenhunen JD. 2000. Effects of long-term rainfall variability on evapotranspiration and soil water distribution in the Chihuahuan Desert: A modeling analysis. Plant Ecology 150, 145-159. https://doi.org/10.1023/A:1026530522612
Scanlon TM, Kustas WP. 2010. Partitioning carbon dioxide and water vapor fluxes using correlation analysis. Agricultural and Forest Meteorology 150, 89-99. https:// doi.org/10.1016/j.agrformet.2009.09.005

Schlesinger WH, Jasechko S. 2014. Transpiration in the global water cycle. Agricultural and Forest Meteorology 189-190, 115-117. https://doi.org/10.1016/j. agrformet.2014.01.011

Scott RL, Edwards EA, Shuttleworth WJ, Huxman TE, Watts C, and Goodrich DC. 2004. Interannual and seasonal variation in fluxes of water and carbon dioxide from a riparian woodland ecosystem. Agricultural and Forest Meteorology 122, 65-84. https://doi. org/10.1016/j.agrformet.2003.09.001

Scott RL, Huxman TE, Cable WL, Emmerich WE. 2006. Partitioning of evapotranspiration and its relation to carbon dioxide exchange in a Chihuahuan Desert shrubland. Hydrological Processes 20, 3227-3243. https://doi.org/10.1002/hyp.6329

Seibt U, Rajabi A, Griffiths H, Berry JA. 2008. Carbon isotopes and water use efficiency: Sense and sensitivity. Oecologia 155, 441-454. https://doi.org/10.1007/ s00442-007-0932-7

Shuttleworth WJ. 2006. Putting the "vap" into evaporation. Hydrology and Earth System Sciences 11, 210-244. https://doi.org/10.5194/hess-11-210-2007

Sun S, Meng P, Zhang J, Wan X, Zheng N, He C. 2014. Partitioning oak woodland evapotranspiration in the rocky mountainous area of North China was disturbed by foreign vapor, as estimated based on non-steadystate ${ }^{18} \mathrm{O}$ isotopic composition. Agricultural and Forest Meteorology 184, 36-47. https://doi.org/10.1016/j. agrformet.2013.08.006

Stoy PC, El-Madany TS, Fisher JB, Gentine P, Gerken T, Good SP, Klosterhalfen A, Liu S, Miralles DG, Pérez-Priego O, Rigden AJ, Skaggs TH, Wohlfahrt G, Anderson RG, Coenders-Gerrits AMJ, Jung M, Maes WH, Mammarella I, Mauder M, Migliavacca M, Nelson JA, Poyatos R, Reichstein M, Scott RL, Wolf S. 2019. Reviews and syntheses: Turning the challenges of partitioning ecosystem evaporation and transpiration into opportunities, Biogeosciences 16, 3747-3775. https://doi.org/10.5194/bg-16-3747-2019

Tarin T, Yépez EA, Garatuza-Payán J, Watts CJ, Rodríguez JC, Vivoni ER, Méndez-Barroso LA. 2014. Evapotranspiration partitioning with stable isotopes in ecohydrological studies. Water Technology and Sciences 5, 97-114. 
Tarin T, Nolan RH, Medlyn BE, Cleverly J, Eamus D. 2020. Water-use efficiency in a semi-arid woodland with high rainfall variability. Global Change Biology 26, 496-508. https://doi.org/10.1111/gcb.14866

Vargas R, Yépez EA, Andrade JL, Ángeles G, Arredondo T, Castellanos AE, Garatuza-Payán J, González del Castillo E, Oechel W, Rodríguez JC, Sánchez-Azofeifa A, Vivoni ER, Watts CJ. 2013. Progress and opportunities for monitoring greenhouse gases fluxes in Mexican ecosystems: the MexFlux network. Atmósfera 26, 325-336.

Verduzco VS, Vivoni ER, Yépez EA, Rodríguez JC, Watts CJ, Tarin T, Garatuza-Payán J, Robles-Morua A, Ivanov VY. 2018. Climate change impacts on net ecosystem productivity in a subtropical shrubland of northwestern México. Journal of Geophysical Research: Biogeosciences 123, 688-711. https://doi. org/10.1002/2017JG004361

Villarreal S, Vargas R, Yepez EA, Acosta J, Castro A, Escoto-Rodríguez M, López E, Martínez-Osuna J, Rodríguez JC, Smith S, Vivoni ER, Watts CJ. 2016. Intra-and inter-annual variability of evapotranspiration in two water-limited ecosystems with contrasting precipitation patterns. Journal of Geophysical Research: Biogeosciences 121, 494-508. https://doi.org/10.1002/2015JG003169

Vivoni ER, Moreno HA, Mascaro G, Rodriguez JC, Watts CJ, Garatuza-Payán J, Scott RL. 2008. Observed relation between evapotranspiration and soil moisture in the North American monsoon region. Geophysical Research Letters 35, L22403. https://doi. org/10.1029/2008GL036001

Vivoni ER, Watts CJ, Rodriguez JC, Garatuza-Payán J, Méndez-Barroso LA, Saiz-Hernández JA. 2010. Improved land-atmosphere relations through distributed footprint measurements in a subtropical scrubland during the North American Monsoon. Journal of Arid Environments 74, 579-584. https://doi.org/10.1016/j.jaridenv.2009.09.031

Vivoni ER. 2012. Diagnosing seasonal vegetation impacts on evapotranspiration and its partitioning at the catchment scale during SMEX04-NAME. Journal of Hydrometeorology 13, 1631-1638. https://doi.org/10.1175/ JHM-D-11-0131.1

Wang L, Caylor KK, Villegas JC, Barron-Gafford GA, Breshears DD, Huxman TE. 2010. Partitioning evapotranspiration across gradients of woody plant cover: Assessment of a stable isotope technique. Geophysical Research Letters 37, 1-7. https://doi. org/10.1029/2010GL043228
Wang L, Good SP, Caylor KK. 2014. Global synthesis of vegetation control on evapotranspiration partitioning. Geophysical Research Letters 41, 6753-6757. https:// doi.org/10.1002/2014GL061439

Wang XF, Yakir D. 2000. Using stable isotopes of water in evapotranspiration studies. Hydrological Processes 14, 1047-1421. https://doi.org/10.1002/10991085(20000615)

Wang P, Yamanaka T, Lia,X-Y, Wei Z. 2015. Partitioning evapotranspiration in a temperate grassland ecosystem: Numerical modeling with isotopic tracers. Agricultural and Forest Meteorology 208, 16-31. https://doi. org/10.1016/j.agrformet.2015.04.006

Watts CJ, Scott RL, Garatuza-Payán J, Rodríguez JC, Prueger JH, Kustas WP, Douglas M. 2007. Changes in vegetation condition and surface fluxes during NAME 2004. Journal of Climate 20, 1810-1820. https://doi. org/10.1175/jcli4088.1

Wenninger J, Beza DT, Uhlenbrook S. 2010. Experimental investigations of water fluxes within the soil-vegetation-atmosphere system: Stable isotope mass-balance approach to partition evaporation and transpiration. Physics and Chemistry of the Earth, Parts A/B/C 35, 565-570. https://doi.org/10.1016/j. pce.2010.07.016

West AG, Patrickson SJ, Ehleringer JR. 2006. Water extraction times for plant and soil materials used in stable isotope analysis. Rapid Communication in Mass Spectrometry 20, 1317-1321. https://doi.org/10.1002/ rcm. 2456

Wei, Z., Lee, X., Wen, X. and Xiao, W. 2019. Evapotranspiration partitioning for three agro-ecosystems with contrasting moisture conditions: A comparison of an isotope method and a two-source model calculation. Agricultural and Forest Meteorology 252, 296-310. https://doi.org/10.1016/j.agrformet.2018.01.019

Williams DG, Cable W, Hultine K, Hoedjes JCB, Yépez EA, Simonneaux V, Er-Raki S, Boulet G, Bruin de HAR, Chehbouni A, Hartogensis OK, Timouk F. 2004. Evapotranspiration components determined by stable isotope, sap flow and eddy covariance techniques. Agricultural and Forest Meteorology 125, 241-258. https://doi.org/10.1016/j. agrformet.2004.04.008

Wilson KB, Hanson PJ, Mulholland PJ, Baldocchi DD, Wullschleger SD. 2001. A comparison of methods for determining forest evapotranspiration and its components: Sap-flow, soil water budget, eddy covariance 
and catchment water balance. Agricultural and Forest Meteorology 106, 153-158. https://doi.org/10.1016/ S0168-1923(00)00199-4

Xiao W, Lee X, Wen X, Sun X. Zhang S. 2012. Modeling biophysical control on canopy foliage water ${ }^{18} \mathrm{O}$ enrichment in wheat and corn. Global Change Biology 18, 1769-1780. https://doi.org/10.1111/j.13652486.2012.02648.x

Xu Z, Yang H, Liu F, An S, Cui J, Wang Z, Liu S. 2008. Partitioning evapotranspiration flux components in a subalpine shrubland based on stable isotopic measurements. Botanical Studies 49, 351-361.

Yakir D, Sternberg LS. 2000. The use of stable isotopes to study ecosystem gas exchange. Oecologia 123, 297311. https://doi.org/10.1007/s004420051016

Yépez EA, Williams DG, Scott RL, Lin G. 2003. Partitioning overstory and understory evapotranspiration in a semi-arid woodland ecosystem from the isotopic composition of water vapor. Agricultural and Forest Meteorology 119, 53-68. https://doi.org/10.1016/ S0168-1923(03)00116-3
Yépez EA, Huxman TE, Ignace DD, English NB, Weltzin JF, Castellanos AE, Williams DG. 2005. Dynamics of transpiration and evaporation following a moisture pulse in semiarid grassland: A chamber-based isotope method for partitioning flux components. Agricultural and Forest Meteorology 132, 359-376. https://doi. org/10.1016/j.agrformet.2005.09.006

Yépez EA, Scott RL, Cable WL, Williams DG. 2007. Intra-seasonal variation in water and carbon dioxide flux components in a semiarid riparian woodland. Ecosystems 10, 1100-1115. https://doi.org/10.1007/ s10021-007-9079-y

Zhang X, Zwiers FW, Hegerl GC, Lambert FH, Gillett NP, Solomon S, Stott PA, Nozawa T. 2007. Detection of human influence on twentieth-century precipitation trends. Nature 448, 461-465. https://doi.org/10.1038/ nature 06025

Zhou S, Yu B, Zhang Y, Huang Y, Wang G. 2016. Partitioning evapotranspiration based on the concept of underlying water use efficiency. Water Resources Research 52, 1160-1175. https://doi.org/10.1002/2015wr017766. 